\title{
Performance of Ferro-Cement Strengthened Unreinforced Masonry Walls against Reverse Cyclic Loading
}

\author{
Sudhira De Silva and N.T. Abeygunawardana
}

\begin{abstract}
Unreinforced masonry (URM) buildings constitute a significant part of existing buildings in Sri Lanka and especially in the south-eastern region because it is low cost and easy to construct. Past ground tremors had shown that these buildings are highly vulnerable to seismic and ground vibration due to the low strength of brick masonry. In the last two decades, several seismic retrofitting techniques for masonry buildings have been developed and practiced, but rarely validated with experimental results and numerical modelling. The purpose of this study is to develop a seismic retrofitting technique to be adopted with locally available materials and an easy retrofitting method suitable for the particular masonry structures.
\end{abstract}

Brick masonry panels $(600 \times 640 \times 215 \mathrm{~mm})$ were cast and cyclic loading tests were carried out for two types of walls: walls without applying retrofitting technique and walls retrofitted with Ferro-cement belts. Ferro-cement belts have been increasingly used owing to the strength, easy application and low cost. Here, the effect of different retrofitting configurations with Ferro-cement coating on the in-plane cyclic performance of brick walls with openings was examined. Experiments conducted in this study revealed that Ferro-cement belt retrofitted walls horizontally and vertically significantly increased its in-plane strength and ductility capacity.

Keywords: Ferro-cement belt, Seismic retrofitting, Cyclic loading test, Un-reinforced masonry building (URM)

\section{Introduction}

Unreinforced masonry (URM) is among the most commonly used building materials for construction of low-rise buildings and towers from ancient time and even for infill-walls of some high-rise buildings. It is a highly used building material in Asian countries and many other developing countries. Additionally, inherent advantages including aesthetic appearance, heat and sound insulation, fire resistance, economic considerations and sound understanding of its mechanical properties, contribute to its continuing appeal (Chuang et al. [1]).

URM structures have performed poorly during past earthquakes (Kaplan et al. [2]), because most URM buildings are built with little or no consideration of seismic loading. Ground tremors are minor earthquakes and thousands of ground tremors occur every day worldwide (Panagoda [3]). Unfortunately, most of the URM buildings were damaged or collapsed during recent earthquakes in many countries (Kaplan et al. [2]). The most significant earthquake disaster was recorded in 1976 in China, where it was estimated that 240,000 people were killed. Most of the deaths were due to the collapse of brick masonry buildings (Guosheng [4]).

In the past there were few reported significant ground tremors in Sri Lanka. But now, the situation is completely different because areas like Ampara, Monaragala and Badulla are at a risk of ground tremors, and they have already faced some problems due to minor ground tremors.

Therefore, retrofitting the existing URM structures is essential for modification of existing structures to make them more resistant to seismic activity, ground motion, or soil failure due to earthquakes. This involves actions for upgrading the seismic resistance of an existing building, so that it becomes safer under the occurrence of probable future earthquakes (Mendis et al. [5], Munasinghe et al. [6]).

Eng. (Dr.) Sudhira De Silva, PhD (Saitama), MEng (Saitama), PG Diploma (Strut), B.Sc. Eng. (Hons) (Moratuwa), C.Eng., MIE (Sri Lanka), Senior Lecturer, Department of Civil and Environmental Engineering, University of Ruhuna, Sri Lanka. (iD) https://orcid.org/0000-0003-0804-5097

Eng. N.T. Abeygunawardana, B.Sc. Eng. (Hons), AMIE (Sri Lanka) Research Student, Department of Civil and Environmental Engineering, Saitama University, Japan. (iD) https://orcid.org/0000-0002-3341-0706 
In order to do the seismic retrofitting, several techniques can be used to improve the seismic performance of existing URM walls. These include bamboo reinforcement, post-tensioning using scrapped rubber tires and other materials, various types of mesh reinforcements, and some advanced materials like Fiber-reinforced polymers (FRP) and engineered cementitious composites (ECC), which are efficient though costly (Kadam [7]). Among these methods, seismic retrofit of URM walls was performed using Ferro-cement belt because it is thinner and lighter, stronger, and easier and faster to install.

\section{Methodology}

\subsection{Preparation of wall panels}

An experimental programme was carried out for various strengthening techniques. Walls with and without window openings were used in the experiments. Before strengthening works, all the walls were constructed to dimensions of $600 \times 640 \times 215 \mathrm{~mm}$. The dimensions of the wall panels were selected considering an aspect ratio of 1.1 (height/width) and the selected bond pattern was English bond. The size of the brick was $215 \times 105 \times 60 \mathrm{~mm}$ and the thickness of the mortar used was $10 \mathrm{~mm}$. Cement sand mortar of 1:6 ratio was used for the mortar bed joints. The opening, $225 \times 200 \mathrm{~mm}$, was positioned at the middle of the wall panel.

The retrofitting work was carried out with different Ferro-cement belt configurations. Rich cement sand mortar of 1:3 ratio was used for the retrofitting work. The width of the Ferrocement belt was $100 \mathrm{~mm}$ considering the wall dimensions. Firstly, the cement-sand mortar layer was applied on the wall considering the retrofitting configuration. Before cement-sand mortar layer was dried out a steel wire mesh of $3 \mathrm{~mm}$ mesh size was fixed to the wall using nails, and another cement-sand mortar layer was applied on top of that. These steps are shown in Figure 1.

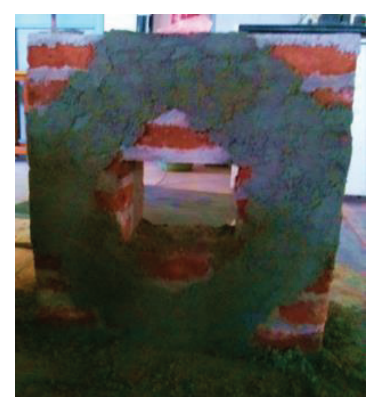

(a)

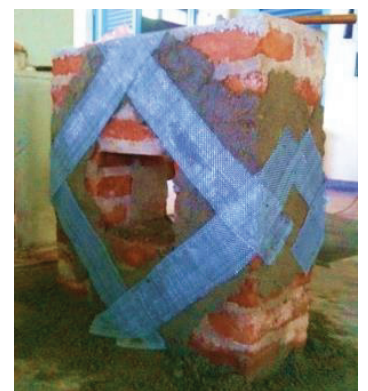

(b)

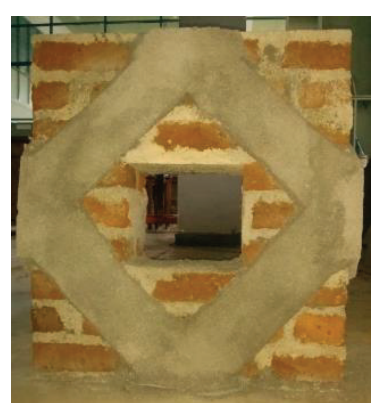

(c)

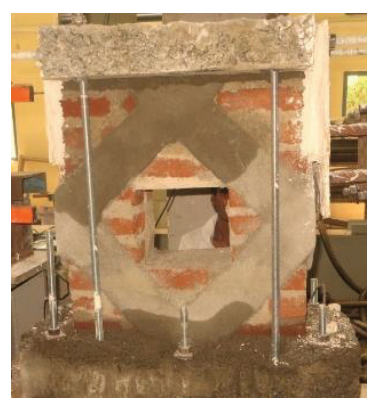

(d)
Figure 1 - (a) Application of first mortar layer,

(b) Applying steel mesh, (c) Covering the wrapped area using mortar (d) Clamped into the Loading Set-up

Figure 2 and Table 1 show the different Ferrocement belt configurations used and their notations for the cyclic loading tests.

\section{Table 1 - Test Specimen Specifications}

\begin{tabular}{|l|l|}
\hline $\begin{array}{l}\text { Specimen } \\
\text { Name }\end{array}$ & Description \\
\hline C & Control without opening \\
\hline CWO & Control with opening \\
\hline HWO & $\begin{array}{l}\text { Retrofitted using horizontal } \\
\text { Ferro-cement belt with opening }\end{array}$ \\
\hline VWO & $\begin{array}{l}\text { Retrofitted using vertical Ferro- } \\
\text { cement belt with opening }\end{array}$ \\
\hline DWO & $\begin{array}{l}\text { Retrofitted using vertical and } \\
\text { horizontal Ferro-cement belt } \\
\text { with opening }\end{array}$ \\
\hline & $\begin{array}{l}\text { Retrofitted using diagonal Ferro- } \\
\text { cement belt with opening }\end{array}$ \\
\hline
\end{tabular}

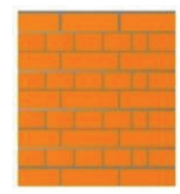

C

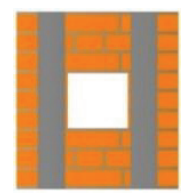

VWO

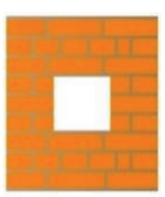

CWO

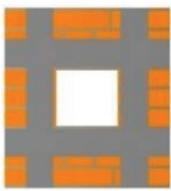

HVWO

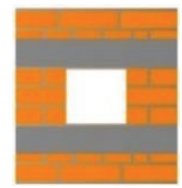

HWO

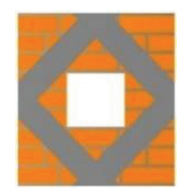

DWO
Figure 2 - Retrofitting configurations

\section{$2.2 \quad$ Cyclic loading tests}

The walls were subjected to in-plane shear forces according to a predefined cyclic loading pattern to examine the seismic behaviour of masonry wall panels. The effect of the ground tremors can be closely simulated in the form of the cyclic loading tests because the direction of the applied load varied from time to time and the wall is subjected to shaking. 
Loads from roof and other accessories acting on the wall, dead load $\left(0.75 \mathrm{kN} / \mathrm{m}^{2}\right)$ and imposed load $\left(0.75 \mathrm{kN} / \mathrm{m}^{2}\right)$, were represented by the top beam $(350 \times 600 \times 100 \mathrm{~mm})$. The foundation beam was installed mainly to tie the wall panel to the foundation. A $150 \mathrm{~mm}$ high precast concrete pad was used and width of the beam was larger than the width of the wall. Additional length was used to clamp the wall to foundation beam as well as to the top beam and to the apparatus as shown in Figure 3.

The wall panel was placed at the top of the foundation beam by applying a cement-sand mortar layer. In addition to that, another concrete layer was placed around the wall for better tightness. Then the top beam was placed on top of the wall panel by applying another cement sand mortar layer in order to apply the axial load before the application of lateral load. Concrete admixtures were used to get early strength of the concrete. The wall was braced using thread bars going through the top and foundation beams, and also the foundation beam was bolted to the strong floor in order to prevent out-of-plane deflections (Figure 1(d) and Figure 3). Figure 4 shows the clamping arrangement of the test setup.

Steel Plate-1 setup was arranged to transfer load applied from the Server Control Static \& Dynamic actuator (capacity of $300 \mathrm{kN}$ ) to the wall panel. Steel Plate-2 on the opposite side of the actuator was to get the backward force.

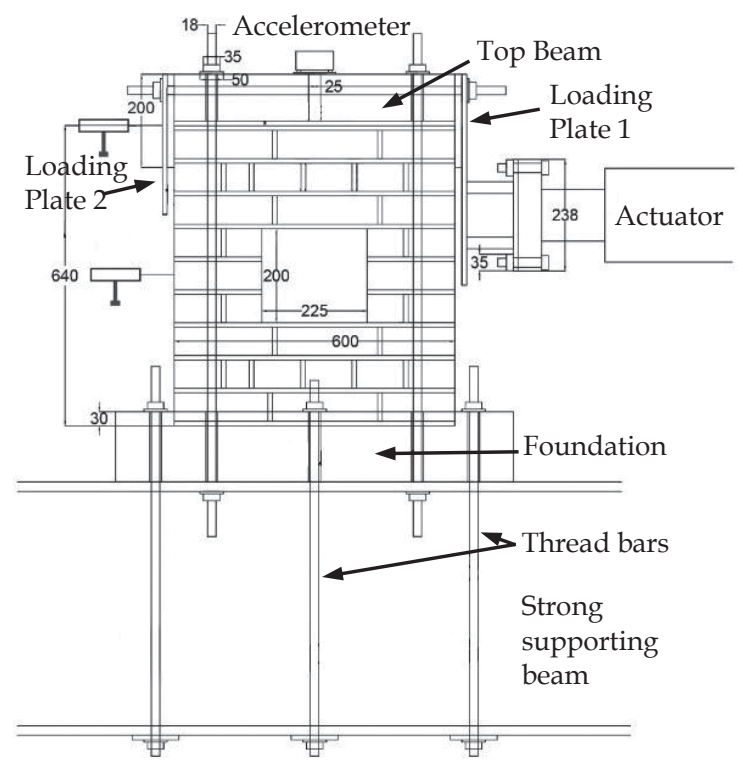

Figure 3 - Schematic diagram of test setup

Figure 4 shows two steel plates, bolted using two thread bars going through the top beam. These steel plates were properly fixed to the wall panel using a strong cement mortar layer in order to get the proper transmission of the load.

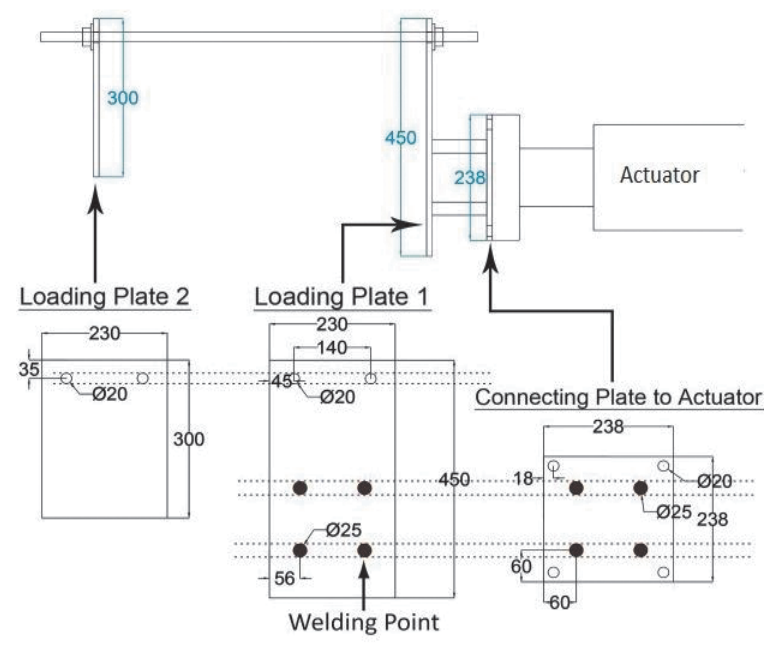

Figure 4 - Steel plate arrangement of setup

Two displacement gauges (Linear Variable Differential Transformer (LVDT), $25 \mathrm{~mm}$ ) were set to the wall panel in order to measure the top and middle displacements of the wall panel. All these walls were tested under constant vertical load (gravity load) and an incrementally increasing in-plane sinusoidal wave form which was applied on top of the wall panel to obtain hysteretic behaviour.

The selected loading pattern, which is very close to actual behaviour of earthquake, can simulate the earthquake action and its effect on the wall. The applied force and the corresponding stroke, wall middle and wall top displacements were measured using TDS-630 (Tokyo Sokki) data actuation system. The propagation of cracks was also identified and marked at each loading stage. The details of the given cyclic loading are shown in Figure 5. The input cyclic loading pattern was plotted by considering 100 numbers of repeaters as one.

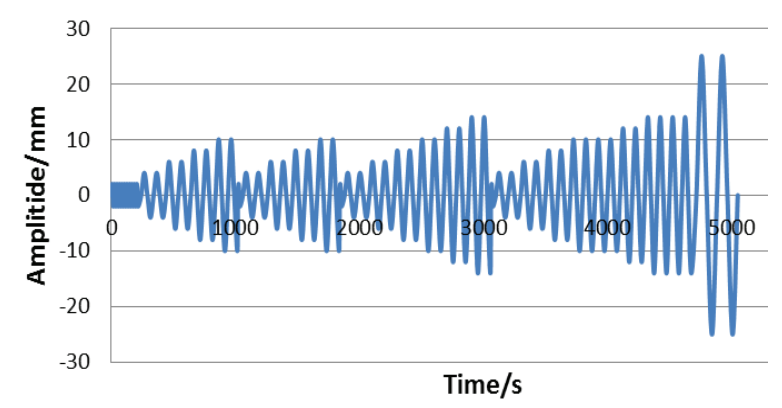

Figure 5 - Input cyclic wave form 


\section{Results and Discussion}

\subsection{Crack propagation}

The six walls tested had the same aspect ratio and included four retrofitted walls using Ferrocement belts as shown Figure 6 .

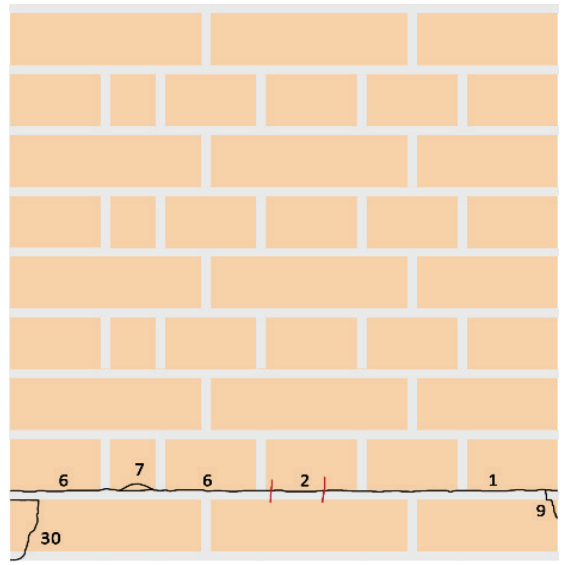

Two controls and four different configurations of retrofitted walls were investigated against reverse cyclic loading.

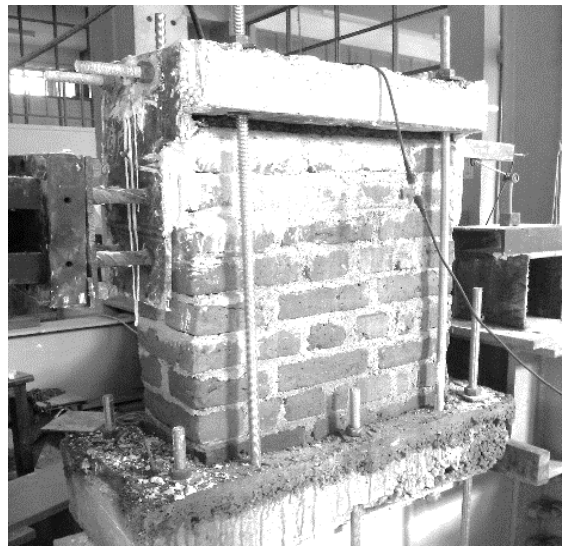

(a) $\mathrm{C}$ (Control without opening)
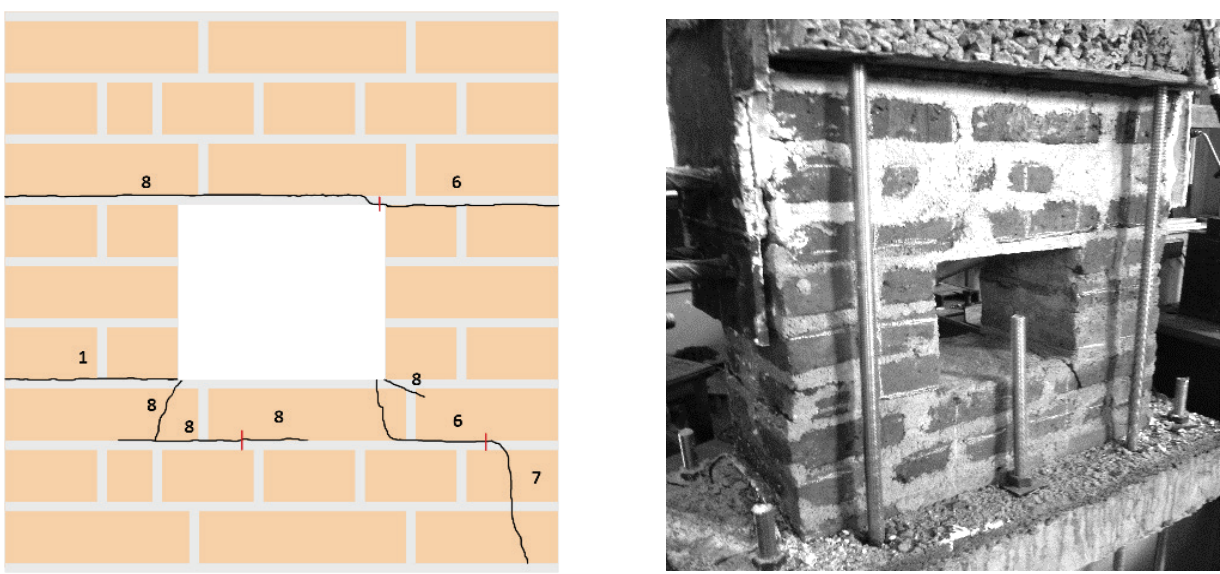

(b) CWO (Control with opening)
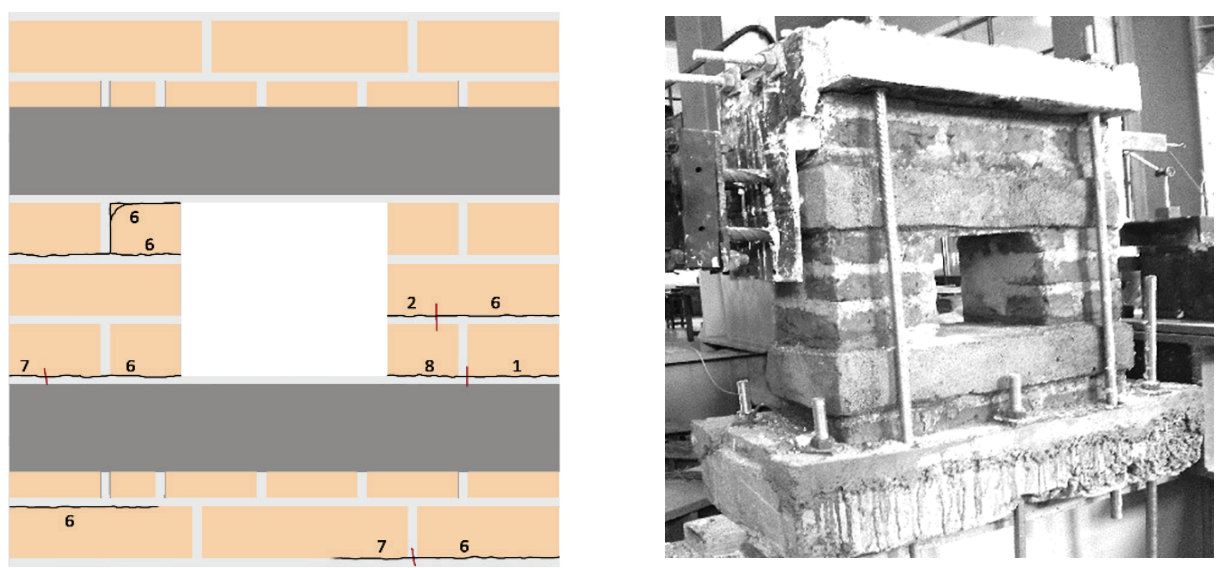

(c) HWO (Retrofitted using horizontal Ferro-cement belt with opening) 

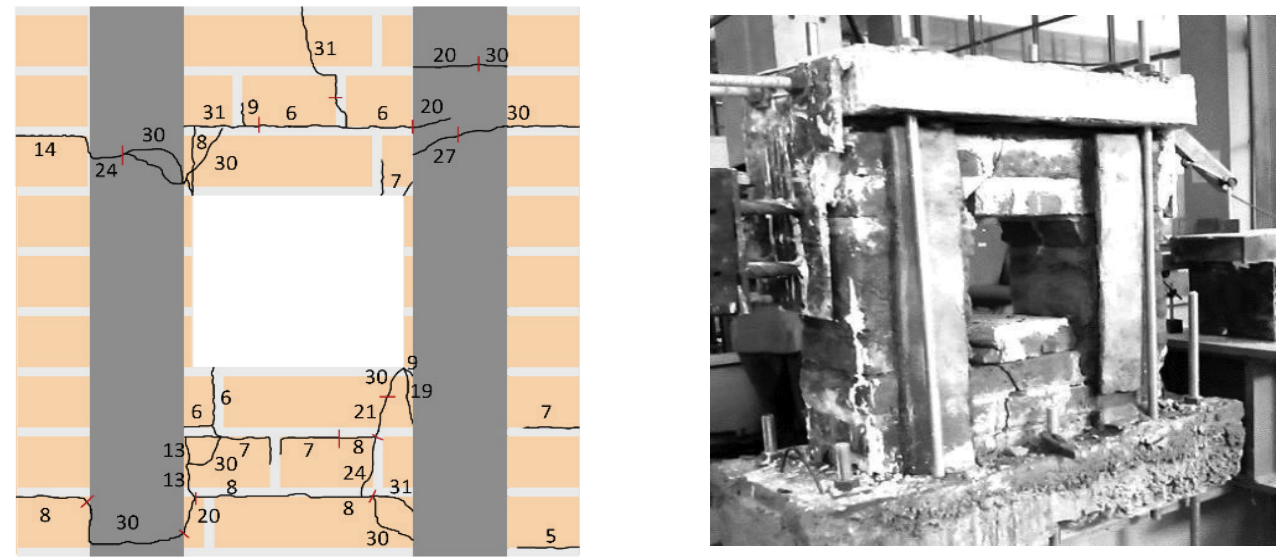

(d) VWO (Retrofitted using vertical Ferro-cement belt with opening)
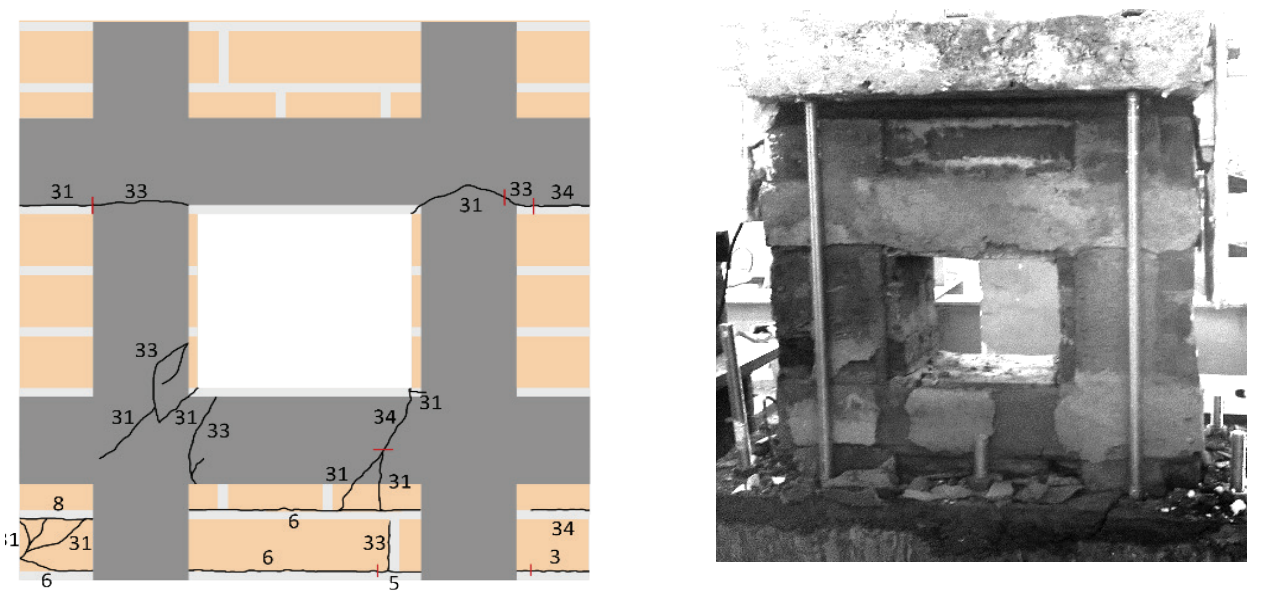

(e) HVWO (Retrofitted using vertical and horizontal Ferro-cement belt with opening)
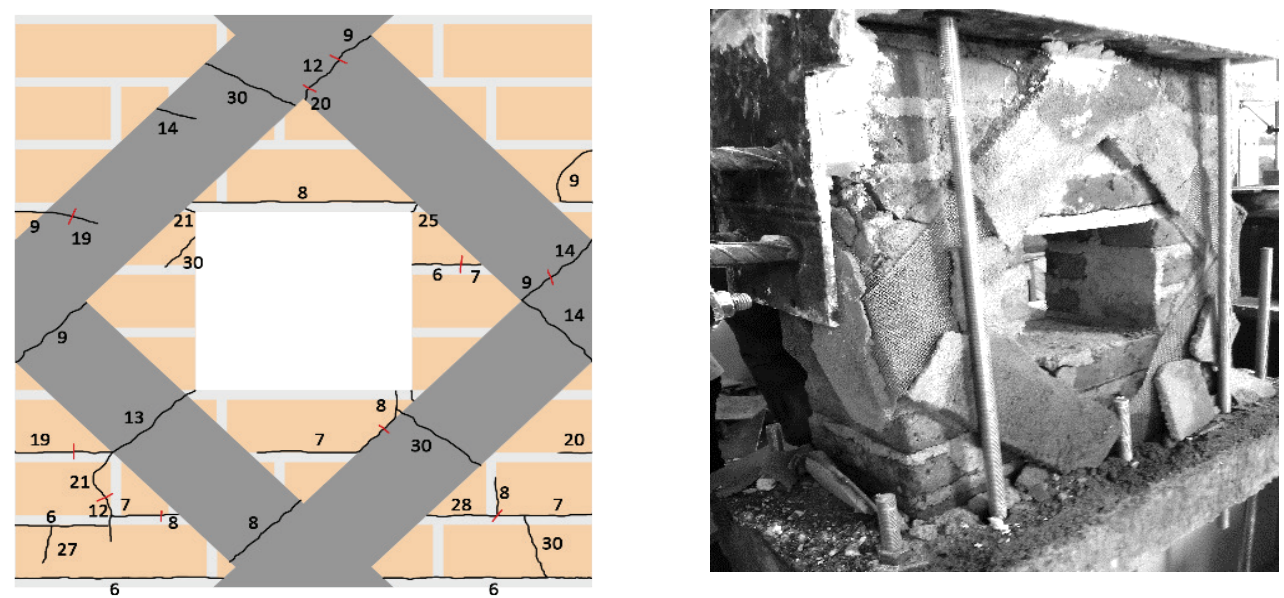

(f) DWO (Retrofitted using diagonal Ferro-cement belt with opening)

Figure 6 - Crack propagations and failure modes of wall panels

In the case of the wall C (Figure 6(a)), cracks appeared at the bottom of the second layer. If there wasn't laid concrete layer around the wall panel the cracks may have appeared at the foundation level. Therefore, in the actual situation when there are no openings (wall C), cracks will appear at the bottom of the foundation level. The first major crack appeared at the $1^{\text {st }}$ loading stage and wall panel totally failed after the $7^{\text {th }}$ loading stage. The bottom brick layer was also damaged when further increasing the load after the $7^{\text {th }}$ loading stage.

When there is an opening (CWO) in the panel, the cracks start to propagate at the edges of the opening and spread through the interface between brick and mortar layers (Figure 6(b)). 
The diagonal cracks appeared at the bottom of the opening corners. These cracks can spread to the foundation level easily. The first major crack appeared at the $1^{\text {st }}$ loading stage and wall panel totally failed after the $6^{\text {th }}$ loading stage.

For the wall panel HWO (Figure 6(c)), the crack propagation at the top of the opening completely reduced due to the top horizontal Ferro-cement belt. No diagonal cracks appeared and most of the cracks were horizontal. The first major crack propagation started at the $1^{\text {st }}$ loading stage and it totally failed at the $8^{\text {th }}$ loading stage. Here the residual strength before the total failure is larger than that at the CWO wall panel. It means wall HWO has more resistance than the wall CWO.

In the case of wall panel VWO (Figure 6(d)), cracks initially appeared at the foundation level. After the next loading stage cracks propagated from the wall opening and there were some diagonal cracks also. But the cracks started to appear at the $5^{\text {th }}$ loading stage. This loading stage is higher compared to that of walls C, CWO and HWO. The wall could withstand more loading without total failure until the loading stage 30 . Therefore, this retrofitting method is more effective than wall HWO.

In the case of wall panel DWO (Figure 6(e)) initial cracks propagated along the foundation level and near to the opening area. The first major crack appeared at the $6^{\text {th }}$ loading stage and wall panel totally failed after the $30^{\text {th }}$ loading stage. There were many diagonal cracks on the retrofitting areas. Therefore, this is not more effective than wall HVWO but it could be withstanding more load than walls $\mathrm{C}$, CWO, HWO and VWO.

In the HVWO wall panel (Figure 6 (f)) cracks started to propagate from the foundation level at the $2^{\text {nd }}$ loading stage. After the propagating cracks at the foundation level, there were no significant cracks before the $30^{\text {th }}$ loading stage. Further increased loading condition initiated the cracks around the wall opening including the diagonal cracks. But all other walls totally failed when starting the $30^{\text {th }}$ loading stage. Therefore, the wall HVWO retrofitting configuration is more effective compared to wall retrofitting configurations of $\mathrm{CWO}, \mathrm{HWO}$, VWO, and DWO.
The loading stage, amplitude at the particular loading stage and failure description are summarized in Table 2.

Load displacement hysteresis curves for all specimens were obtained as shown in Figure 7.

Table 2 - Crack propagation and failure

\begin{tabular}{|c|c|c|c|}
\hline \multirow{2}{*}{$\begin{array}{l}\text { Wall } \\
\text { Panel }\end{array}$} & \multicolumn{2}{|c|}{$\begin{array}{l}\text { Loading Stage / } \\
\text { Amplitude (mm) }\end{array}$} & \multirow{2}{*}{$\begin{array}{c}\text { Failure } \\
\text { Description } \\
\text { (Considering } \\
\text { until 30th stage } \\
\text { of loading) }\end{array}$} \\
\hline & $\begin{array}{c}\text { Initial } \\
\text { cracking }\end{array}$ & $\begin{array}{l}\text { Final } \\
\text { failure }\end{array}$ & \\
\hline $\mathrm{C}$ & $1 / 2$ & $7 / 6$ & $\begin{array}{l}\text { Fail from the } \\
\text { foundation } \\
\text { level }\end{array}$ \\
\hline CWO & $1 / 2$ & $6 / 4$ & $\begin{array}{l}\text { Fail from } \\
\text { the opening } \\
\text { edges }\end{array}$ \\
\hline HWO & $1 / 2$ & $8 / 8$ & $\begin{array}{l}\text { Fail from the } \\
\text { foundation } \\
\text { level } \\
\text { and the } \\
\text { opening edges }\end{array}$ \\
\hline VWO & $5 / 2$ & $30 / 14$ & $\begin{array}{l}\text { More cracks in } \\
\text { between the } \\
\text { vertical strips }\end{array}$ \\
\hline HVWO & $2 / 2$ & $34 / 25$ & $\begin{array}{l}\text { Some cracks at } \\
\text { the foundation } \\
\text { level but fail at } \\
\text { highest } \\
\text { loading stage } \\
\text { compared } \\
\text { with other all } \\
\text { specimens }\end{array}$ \\
\hline DWO & $6 / 4$ & $30 / 14$ & $\begin{array}{l}\text { Fail from the } \\
\text { foundation } \\
\text { level }\end{array}$ \\
\hline
\end{tabular}

\subsection{Ductility factor}

Ductility value of each specimen was found from the Load vs. Displacement curves as shown in Figure 7. The ductility factor from the hysteresis curve is calculated as the fraction of ultimate displacement and the displacement based on the $20 \%$ of ultimate load degradation at failure using Equation (1) (Salloum et al. [8]).

$$
\text { Ductility Factor }=\frac{\begin{array}{c}
\text { Ultimate } \\
\text { Displacement }
\end{array}}{\begin{array}{c}
\text { Displacement at } 20 \% \\
\text { Drop of Peak }
\end{array}}
$$

Table 3 shows the ductility factors of each wall panel. It clearly shows the improvement in the ductility capacity of retrofitted walls. 

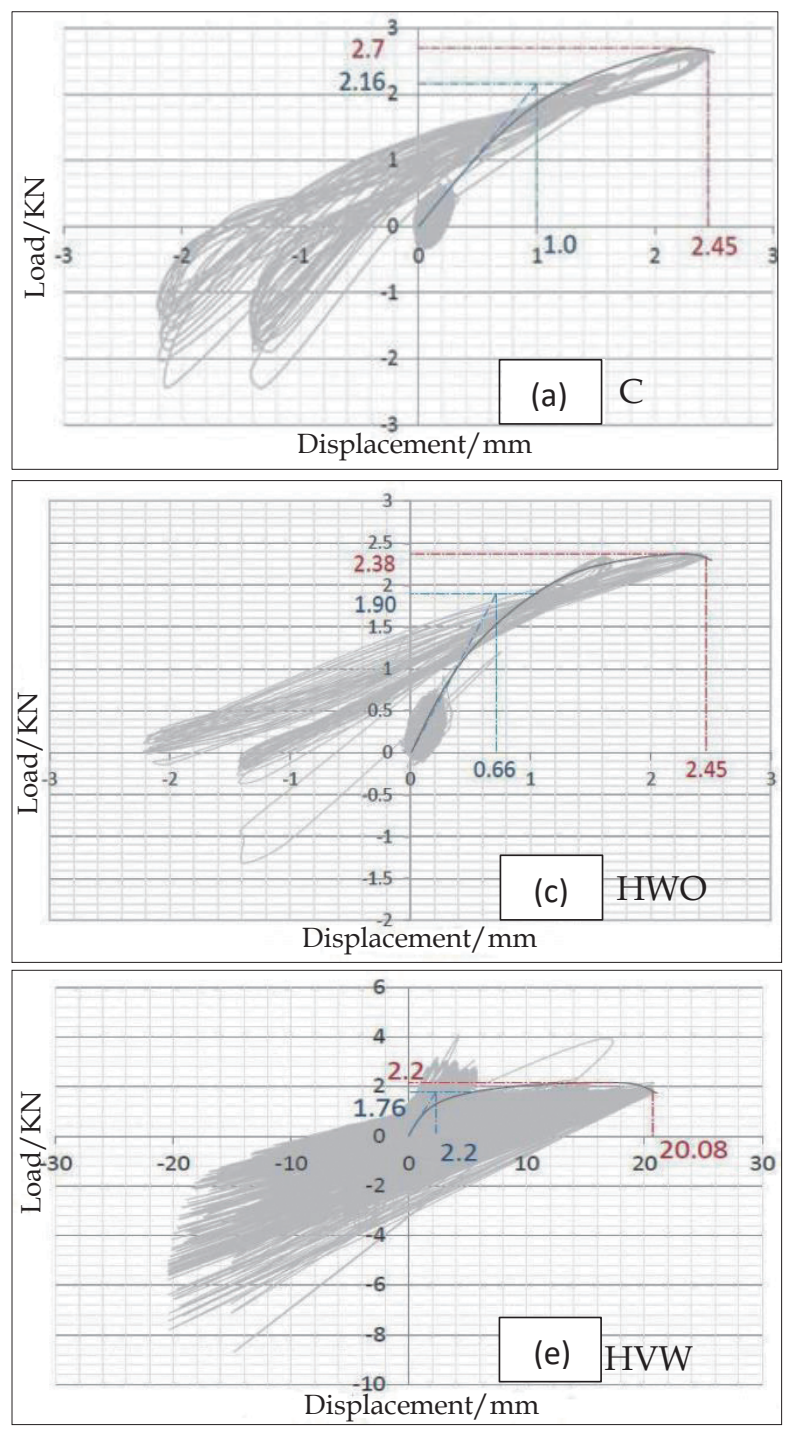
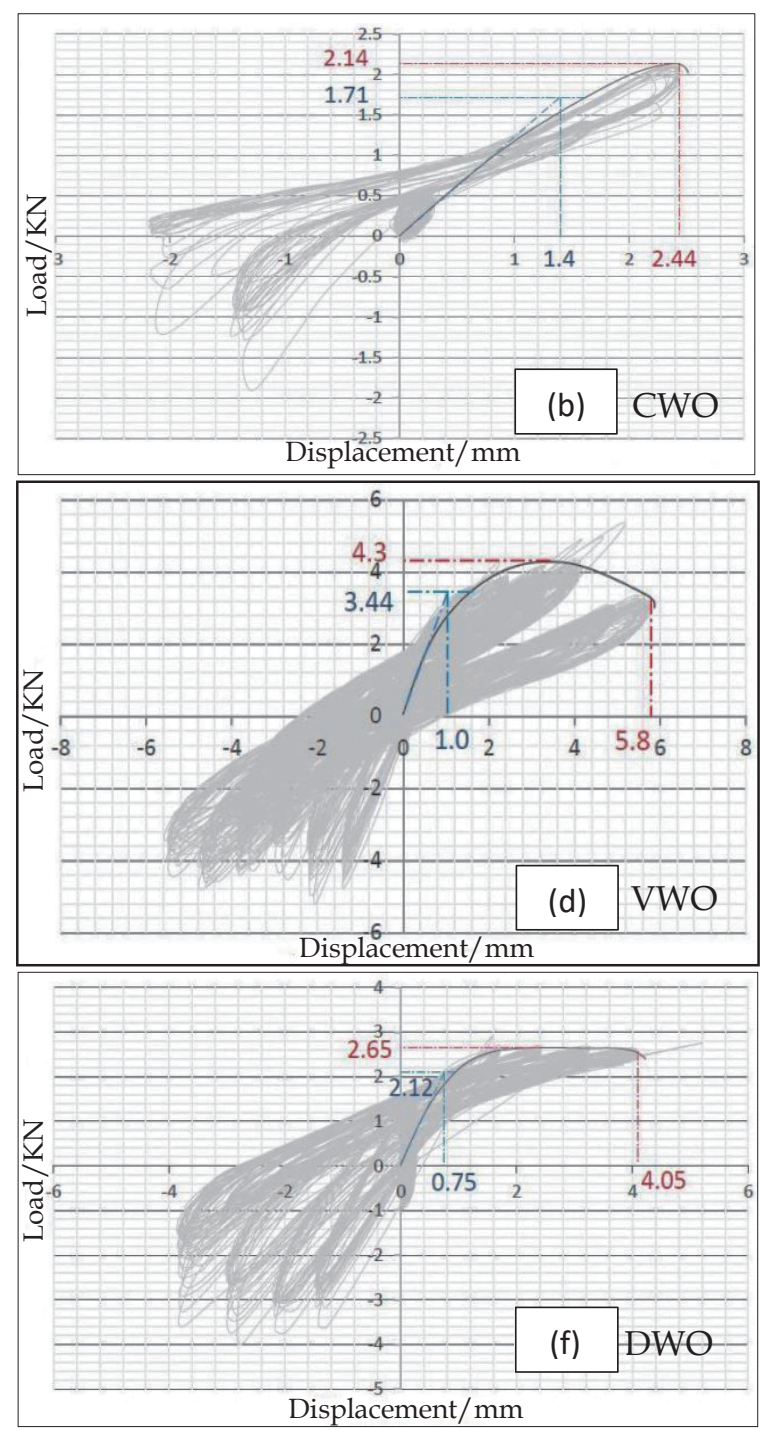

Figure 7 - Hysteretic Curves for wall panels

Table 3 - Ductility factors

\begin{tabular}{|c|c|c|c|}
\hline Specimen & $\begin{array}{c}\text { Ultimate } \\
\text { displacement } \\
(\mathrm{mm})\end{array}$ & $\begin{array}{c}\text { Displacement } \\
\text { at 20\% drop } \\
\text { of peak (mm) }\end{array}$ & $\begin{array}{c}\text { Ductility } \\
\text { factor }\end{array}$ \\
\hline C & 2.45 & 1.00 & 2.45 \\
\hline CWO & 2.44 & 1.40 & 1.74 \\
\hline HWO & 2.45 & 0.66 & 3.71 \\
\hline VWO & 5.80 & 1.00 & 5.80 \\
\hline HVWO & 20.08 & 2.2 & 9.13 \\
\hline DWO & 4.05 & 0.75 & 5.40 \\
\hline
\end{tabular}

Against the reverse cyclic loading is significantly improved in the case of retrofitted walls.

Wall CWO has the lowest ductility factor and ductility factors of retrofitted walls (Wall HWO, VWO, HVWO and DWO) are higher. As discussed in Section 3.1, the resistance against the loading is improved in the case of retrofitted walls. Table 3 shows wall HVWO has high performance against crack propagation and failure. Table 3 also shows higher value of ductility factor for the wall HVWO. Therefore, this retrofitting configuration is more effective than walls $\mathrm{CWO}$, $\mathrm{HWO}, \mathrm{VWO}$, and DWO. In the case of wall HWO and VWO, the wall VWO has higher ductility capacity.

\section{Conclusions}

The performance of ferro-cement strengthened unreinforced masonry walls against reverse cyclic loading was examined. Experiments conducted in this study show that Ferro-cement belt retrofitted walls significantly increase its inplane strength and ductility capacity. A large increase in ductility, up to $500 \%$, was achieved with Ferro-cement belt applied horizontally and vertically (HVWO). The specimen VWO and 
DWO also give significant increase in ductility up to $330 \%$ and $310 \%$. According to the crack patterns, the strengthening of the foundation level is also a very important parameter because it has a significant effect on the cyclic load capacity.

\section{Acknowledgement}

The authors would like to express their gratitude to National Research Council for providing necessary financial support under research grant of NRC 11-193 and to the Department of Civil and Environmental Engineering, Faculty of Engineering, University of Ruhuna for the support provided to carry out the research work successfully. The authors also wish to thank Ms. Sumudu Mendis, MPhil Research Student for the support given to carryout testing.

\section{References}

1. Chuang, S. W., Zhuge, Y., Wong, T. Y. and Peters L., 'Seismic Retrofitting of Unreinforced Masonry Walls by FRP Strips', Paper presented at the 2003 Pacific Conference on Earthquake Engineering, Australia.

2. Kaplan, H., Yilmaz, S, Nohutcu, H., Cetinkaya \& Binici N. 2008, 'Experimental Study on the Use of Old Tyres Foreeismic Strengthening of Masonry Structures', Proceedings of the 14th World Conference on Earthquake Engineering, Beijing, China,2008.

3. Panagoda, C., Tremors in Ampara Leave Villagers Shaken and Officials guessing, Available from: $<$ http://www.sundaytimes.lk/121216/news/tremorsin-ampara-leave-villagers-shaken-and-officialsguessing-25020.html > [accessed on 28 May 2013].

4. Guosheng Q. U., “China's Engagement in NonTraditional Security: Challenges and Opportunities for UK-China Military Cooperation", Report submitted to the University of Nottingham and Royal United Services Institute, September 2011, pp 21-22.

5. Mendis, W. S. W., De Silva, G. S. Y., and De Silva, G. H. M. J. S., “Performance and Retrofitting of Un-reinforced Masonry Building against Natural Disasters - A Review Study 'Journal of the Institution of Engineers, "ENGINEER", Vol. XLVII, No. 3, July 2014, pp 71-82.

6. Munasinghe, T., Curray, J. R., "Possible Cause of Recent Earthquakes around Ampara, Sri Lanka: Constrains from the Earthquake Distribution in the Northeast Indian Ocean", Proceedings to 29th Technical Sessions of Geological Society of Sri Lanka, 2013, pp. 1-3.
7. Kadam, S. B, Singh, Y, Li, B, 2014, 'Strengthening of Unreinforced Masonry Using Welded Wire Mesh and Micro-Concrete - Behaviour Under InPlane Action', Journal of Construction and Building Materials February 2014, Vol. 54, pp. 247257.

8. Salloum, Y. A., Alsayed, S. H., Almusallam, T. H. and Siddiqui, N. A., 'Behaviour of Full-Scale Shear Deficient Corner RC Beam-Column Connections Retrofitted with CFRP sheets.' Report Submitted to the Department of civil engineering, King Saud University, Riyadh 11421, Saudi Arabia, 2007. 